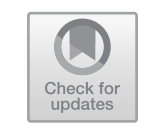

\title{
The Legacy of Vattel's Droit des gens: Contexts, Concepts, Reception, Translation and Diffusion
}

Koen Stapelbroek and Antonio Trampus

The DROIT DES GENS:

Its Character and Its Multifarious Legacy

Emer de Vattel's Le Droit des gens, ou principes de la loi naturelle appliqués à la conduite et aux affaires des nations et des souverains was first published in 1758, following a longish gestation period (1753-1757). The book was preceded by a series of short publications, notably essays on philosophical, moral, legal and literary subjects, published by Vattel since the late 1740s. In the immediate aftermath of its appearance at the height of the Seven Years' War, the Droit des gens became the object of academic and political discussion and of quick reprints, including pirate

K. Stapelbroek $(\square)$

Erasmus University Rotterdam, The Netherlands

e-mail: stapelbroek@essb.eur.nl
A. Trampus
Ca' Foscari University Venice, Italy

e-mail: trampus@unive.it

(C) The Author(s) 2019

K. Stapelbroek and A. Trampus (eds.),

The Legacy of Vattel's Droit des gens, https://doi.org/10.1007/978-3-030-23838-4_1 
editions. What has often gone unnoticed, however, also in recent studies, is the fact that Vattel's lasting fame was not, or not just, an instant effect of the initial reception of his main work. The Droit des gens had a somewhat atypical reception history. It spread throughout Europe on a much larger scale after its second enlarged edition was published in 1773 (seven years after the author's death). During the 1770s and 1780s the work diffused, not primarily as a work on international law or commentary on war and diplomacy, but as a text that gave direction to the reform of small states' foreign trade and political relations with other states. From the later eighteenth century, coinciding with the War of the American Independence and the lead up to the French Revolution, the diffusion of the Droit des gens accelerated. Within a century of its first appearance over twenty French editions saw the light. In addition, ten British, twelve American and several Italian, German and other translations into European languages appeared. Vattel's Droit des gens remained a key text, a true classic, in the field of international law until as late as the early twentieth century. ${ }^{1}$ Given the temporal and spatial complexity of this reception history, to speak of the legacy of Vattel's Droit des gens in the singular might easily lead to misleading suggestions and undesirable reductionism.

Several factors can be identified to account for the lasting and multifarious legacy of the Droit des gens. Beyond its apparent contextual relevance to the military and diplomatic circumstances of the Seven Years' War, the Droit des gens masterly united political theory and philosophical conceptual innovation and reshaped the discourse of natural law in a manner that proved exemplary to later generations. Its stated aim, in the opening pages, to not primarily or exclusively address an academic audience but a wider public of educated functionaries, diplomats and other readers was reflected in the simple hierarchical structure and clear linguistic presentation of the text, simultaneously eschewing philosophical over-abstraction and indulgence in specific political and legal-diplomatic detail. In this way, the argument of the Droit des gens responded to a widely perceived urge to come to grips with the foundations of the

\footnotetext{
${ }^{1}$ Elisabetta Fiocchi Malaspina, L'eterno ritorno del Droit des gens di Emer de Vattel (secc. XVIII-XIX), L'impatto sulla cultura giuridica in prospettiva globale (Frankfurt: Max Planck Institute, 2017) reconstructs the long publishing history of Vattel's Droit des gens and its contexts.
} 
eighteenth-century transformation of interstate political and economic relations. $^{2}$

Indeed, not only the language (the vernacular), the accessible style and broadly appealing presentation contributed to the lengthy and differentiated reception of the work. The very architecture of the Droit des gens was designed to be more than a legal, philosophical, political or moral perspective on the time in which it emerged, but a comprehensive engagement with the nature and conceptual hierarchy of the challenges of the time. From the programmatic preface onwards, Vattel attempted to replace the large number of distinctions that previous scholars had operated with a conceptual lexicon that performed the task of differentiating between types of law, in the first place between the Law of Nature and the Law of Nations. The 28 paragraphs of the preliminaries further formalised this specific differentiation and offered a set of definitions as to how the Law of Nations should be understood. The 23 chapters of book I subsequently focused on "Nations considered in themselves", and operationalised the encapsulation of the law of nature in the ideas of the nation, the constitution and the accountability of rulers to the natural interests of the people. In book II, consisting of 18 chapters, on the "Nation considered in its Relation with others", Vattel took a further step away from the law of nature, but still maintained his original moral principles to circumscribe the freedom with which states could act as sovereigns in the international sphere. While in book III, Vattel engaged, in its 18 chapters, with the principles and regulation of "War", in the same vein as in book II, but through the law of nations generally limiting the extent to which war allowed for natural judgement and the execution of justice. The rights of states to act as sovereign powers in the state of nature were thus consistently doubly monitored by the idea that the law of nations was both grounded in the law of nature but still a proper positive law. Finally, the 9 chapters of book IV discussed "the restoration of peace" and the diplomatic practices surrounding ambassadorial relations and treaty-making.

While the existing historiography on Vattel's Droit des gens is vast, most studies that engage with the book's legacy (and thereby with

\footnotetext{
${ }^{2}$ What these transformations amounted to, and what theoretical and practical responses they generated is captured by Istvan Hont, Jealousy of Trade: International Competition and the Nation-State in Historical Perspective (Cambridge, MA: Harvard University Press, 2005), esp. 1-156.
} 
Vattel's) have somewhat limited themselves by associating Vattel's work with key issues pertaining to specific academic disciplines as they exist today. ${ }^{3}$ Recently, a number of studies have brought back into focus the nature of Vattel's outlook on the international order by highlighting the context in which the work was written and by tracing its legacy. ${ }^{4}$ Different from the historiographical tendency to focus on the text itself and the retrospective analysis of its theoretical contents and presumed originalities from later developed perspectives and disciplinary formations, precisely such an approach that is more attentive to historical contexts and cultures of reception, discussion and diffusion may open up new theoretical conceptions and categories, including legal and political ones. ${ }^{5}$

${ }^{3} \mathrm{~A}$ recent volume edited by Vincent Chetail and Peter Haggenmacher, Vattel's International Law from a XXIst Century Perspective/Le Droit International de Vattel vu $d u$ XXIe Siècle (Leiden: Martinus Nijhoff, 2011) -with a mix of chapters in French and English - is of undisputedly scholarly quality, yet tends to commit itself to an understanding of Vattel's significance that is restricted to the field of international law today. Likewise, does another classic study by Emmanuelle Jouannet, Emer de Vattel et l'émergence doctrinale $d u$ droit international classique (Paris: Pedone, 1993) and further back F. Stephen Ruddy, International Law in the Enlightenment: The Background of Emmerich de Vattel's Le Droit des gens (New York: Oceana, 1975). Cf. the more comprehensive account by Frederick Whelan, "Vattel's Doctrine of the State", History of Political Thought 9 (1988), 59-90.

${ }^{4}$ A special issue of the journal Grotiana 31(1) (2010), guest edited by Béla Kapossy, includes six highly interesting contributions to Vattel scholarship. Their focus, differently from the presently proposed volume, is mostly on the issue of military intervention and sovereign integrity and the different, indeed contradictory, ways in which Vattel has been seen over time as limiting or expanding justifications for foreign intervention. Simone Zurbuchen, "Vattel's Law of Nations and Just War Theory", History of European Ideas 35 (2009), 408-417; Jennifer Pitts, "Intervention and Sovereign Equality: Legacies of Vattel", Just and Unjust Military Intervention: European Thinkers from Vitoria to Mill, ed. Stefano Recchia and Jennifer M. Welsh (Cambridge: Cambridge University Press, 2013), 132-153 have also engaged with his topic in a highly refined manner.

${ }^{5}$ A slightly earlier book-length publication, Réflexions sur l'impact, le rayonnement et l'actualité de "Le droit des gens, ou Principes de la loi naturelle appliqués à la conduite et aux affaires des Nations et des Souverains" d'Emer de Vattel: à l'occasion du 250ème anniversaire de sa parution, ed. Yves Sandoz (Brussels: Bruylant, 2010) addresses the publication, influence and enduring relevance of the Droit des gens in its three different parts. Yet, most contributions stay at the level of unrevised conference papers and communicate a collection of notes or preliminary observations, rather than that they form finished pieces of research that open up bigger issues. 
The present volume forms a contribution to this new direction in the study of the intellectual history in general and of the works of Vattel in particular and is the product of a number of initiatives which brought together scholars from different academic disciplines to develop a new orientation in the study of Vattel's works. ${ }^{6}$ Based on the results of these international conferences and seminars that took place across Europe and that were generously funded by a host of local, national and European grants organisations, this collection of essays provides an overview of new readings of Vattel's works and their legacy as they have crystallised over the past decade. Transcending more classical interpretative categories, the methodological innovations that underpin the chapters of this volume have inspired the analysis of hitherto unstudied sources, such as archive memoranda and diplomatic correspondences that create new optics of the relation between text and context. Importantly, the chapters establish a redefinition of the temporal arch and modalities of the reception of the central ideas, arguments and conceptual connections contained in the Droit des gens. Rather than claim a single meaning or a mutually consistent set of meanings for the Droit des gens, let alone a continuously paced reception history, the chapters of this volume suggest that the enduring relevance of the Droit des gens, from the later eighteenth to the early twentieth century, is best explained through inquiring into the appeal that the conceptual connections had on their audiences. Through Vattel's work, the terms constitution and peace

${ }^{6}$ Apart from the present work, see Antonio Trampus's forthcoming, The Constitutionalism of Emer de Vattel: Good Government, Small States and International Politics, as well as a number of earlier publications, leading up to the present volume, including: Koen Stapelbroek and Antonio Trampus, "Commercial Reform Against the Tide: Reapproaching the Eighteenth-Century Decline of the Republics of Venice and the United Provinces", History of European Ideas 36 (2010), 192-202; "Vattel's Droit des gens und die Europäischen Handelsrepubliken im achtzehnten Jahrhundert", Der Moderne Staat und "le doux commerce": Staat, Ökonomie und internationals System im politischen Denken der Aufklärung, ed. Olaf Asbach (Baden-Baden: Nomos), 2014, 181204; Antonio Trampus, "Il ruolo del traduttore nel tardo Illuminismo: Lodovico Antonio Loschi e la traduzione italiana del Droit des gens", Il linguaggio del tardo Illuminismo (Rome: Edizioni di Storia e letteratura, 2009); "Vattel's Droit des gens in Italy: The Doctrinal and Practical Model of Government", War, Trade and Neutrality: Europe and the Mediterranean in the Seventeenth and Eighteenth Centuries, ed. Antonella Alimento (Milan: FrancoAngeli 2011); and Koen Stapelbroek, "Universal Society, Commerce and the Rights of Neutral Trade: Martin Hübner, Emer de Vattel and Ferdinando Galiani”, COLLeGIUM: Studies Across Disciplines in Humanities and Social Sciences 3 (2008), 63-89. 
became something of an eighteenth-century hendiadys that accompanied the development of new political languages from the reality of the Peace of Utrecht to the international order put in place at the Congress of Vienna. Through the Droit des gens, the fate of small nations in the arena of eighteenth-century European trade rivalries and hegemonic politics was re-addressed. But in between Vattel's name became an emblem for the helplessness of international law predicated on the precepts of the law of nature (as in Kant's famous parade of lauter leidige Tröster), and subsequently, later in the nineteenth and early twentieth century, an apologist for the justification of war and the failure of the system of positive law to contain all-out general warfare. ${ }^{7}$

In the final instance and in contrast with the fixed and static disciplinary emblems of Vattel as the last main theorist of natural law, or as a paradigmatic balance of power thinker, the idea emerges that the actual usage of the Droit des gens itself generated international law and politics. If so, the interpretative relation between text and historical meaning through diffusion, reception and translation should also reserve the possibility that different, even contradictory, usages of precisely those concepts that were in the original text might explain the legacy and range of influence of a text like the Droit des gens over a longer period of time and wider geographical area. ${ }^{8}$

${ }^{7}$ Isaac Nakhimovsky, "Carl Schmitt's Vattel and the Law of Nations Between Enlightenment and Revolution", Grotiana 31 (2010), 141-164. Famously, Cornelis van Vollenhoven, De drie treden van het volkenrecht (The Hague: Nijhoff, 1918) turned "Vattelian international law" into a shorthand explanation for the degeneration of international law and the outbreak of warfare. On Vollenhoven's project and the nascent Dutch "Gidsland" perception under the header of a "Grotian tradition", see Johanna K. Oudendijk, "Van Vollenhoven's "The Three Stages in the Evolution of the Law of Nations": A Case of Wishful thinking”, Tijdschrift voor Rechtsgeschiedenis 48 (1980), 3-27. Recently, Emmanuelle Tourme-Jouannet, "The Critique of Classical Thought During the Interwar Period: Vattel and Van Vollenhoven", Vattel's International Law from a XXIst Century Perspective, 133-150. See also below.

${ }^{8}$ Indeed a careful analysis of the legal, political and philosophical faultlines in the Vattel reception may reveal shifts in meaning and interpretation that go much beyond the ideological. In this sense, Simone Zurbuchen, "Emer de Vattel on the Society of Nations and the Political System of Europe", System, Order, and International Law: The Early History of International Legal Thought from Machiavelli to Hegel, ed. Stefan Kadelbach, Thomas Kleinlein and David Roth-Isigkeit (Oxford: Oxford University Press, 2017), 263-282 has underlined that the mainstream notion of Vattel as a founding father of positivism is fundamentally misconceived. Nakhimovsky, "Carl Schmitt's Vattel and the Law of Nations" has perceptively noted how recently historians, building upon Schmitt and Koselleck, 
A key focus in this approach that runs through the contributions to this volume is on Vattel's conceptual lexicon. Vattel's understanding and systematic deployment of terms like sovereignty, state, nation, may indirectly explain how Vattel's association with legal positivism, doctrines of foreign (non-)intervention or other disciplinary notions pertaining to International Law and International Relations took shape, but first and foremost was directly related to the contexts of the 1740s and 1750s in which he wrote.

Vattel's conceptual lexicon as representative of his political, economic, moral and international, system, therefore, is a much-needed key both for developing comparisons with Vattel's contemporaries and their systems of thought, as well as to carefully chart where and how usages and interpretations of Vattel's Droit des gens developed focal points and characteristics that were alien to Vattel's original work. ${ }^{9}$ As such, Vattel's conceptual apparatus, in the contributions to this volume, is the hinging point around which the two poles of ideas and reception move. Ideas do not by themselves determine how a book is received and what practical influence or usages it has (let alone "should" have). ${ }^{10}$ Influence does not define the nature of the thinking in the original text(s). The two elements in combination, however, when researched through concepts, contexts, discourses, networks and debates over time create an explanation and reconstruction of "The Legacy of Vattel's Droit des gens".

understood Vattel's project in different terms from contemporaries until the early nineteenth century: of actively and successfully separating the law of nations from natural law to regulate war and create international order (before degenerating into terror), rather than (failing to) ground international society and political order upon shared moral conceptions. Vattel's system, closer to his own context, was not seen to easily justify foreign interventions as instantiations of the voluntary law of nations.

${ }^{9}$ See the chapters by Malt, Stapelbroek and Trampus. We should mention the monograph by Stéphane Beaulac, The Power of Language in the Making of International Law: The Word Sovereignty in Bodin and Vattel and the Myth of Westphalia (Leiden: Martinus Nijhoff, 2004), which deals with semiotic aspects of texts in the construction of the field of international law and Vincent Chetail, "Vattel et la sémantique du droit des gens: une tentative de reconstruction critique", Vattel's International Law from a XXIst Century Perspective, $385-434$.

${ }^{10}$ This is the risk of philosophically exposing or correcting errors and misinterpretations, see Theodore Christov, "Liberal Internationalism Revisited: Grotius, Vattel, and the International Order of States", The European Legacy 10 (2005), 561-584. One way of overcoming is, is to argue that Vattel deliberately planted the seeds of ambiguity in his work, see Ian Hunter, "Vattel's Law of Nations: Diplomatic Casuistry for the Protestant Nation", Grotiana 31 (2010), 108-140. 


\section{Vattel and His Context: The "Law of Nations", Commerce and Human "Perfection"}

Born in the Swiss region of Neuchâtel, Emer de Vattel was a Prussian citizen by birth. ${ }^{11} \mathrm{He}$ had a diplomatic career not in Berlin, but in the minor German power of Saxony. ${ }^{12}$ In later times, the main message of his 1758 magnum opus has often been construed as an ingenious way of deliberately reducing international law to power politics, or as a failed attempt to civilise the behaviour of states. Recent scholarship has shown these judgements themselves to be to some extent products of their own ideological backgrounds and thereby has paved the way for a richer understanding both of the subtleties of Vattel's main work and of its legacy. ${ }^{13}$

The intellectual purpose of Vattel's Droit des gens, as he himself presented it in the preface, was to confront the challenge, which previous seventeenth- and eighteenth-century writers not managed to put to rest, to decisively distinguish the spheres of the law of nature and that of the law of nations. ${ }^{14}$ The solution of this particular problem was crucial in order to put a conceptual barrier between moral disagreement and the perceived political right, potentially also a duty, to intervene in another state's affairs. In other words, Vattel developed a conceptual separation between the realms of the moral or natural and that of the political, where voluntary law dictated that nations recognised one another

${ }^{11}$ The introduction of Emer de Vattel, The Law of Nations, ed. Béla Kapossy and Richard Whatmore (Indianapolis: Liberty Fund, 2008) contains a concise biography of Vattel's life and career. The standard work on Vattel's life and career remains Édouard Béguelin, "En souvenir de Vattel", Recueil de travaux offert par la Faculté de Droit de l'Université de Neuchâtel à la Société Suisse des Juristes (Neuchâtel: Attinger, 1929), 35-176.

${ }^{12}$ See the chapter by Szymanski. Until now, Vattel's diplomatic career in relation to the Droit des gens is best explained by Andre Bandelier, "De Berlin à Neuchâtel: la genèse du Droit des gens d'Emer de Vattel", Schweizer im Berlin des 18. Jahrhunderts, ed. Martin Fontius and Helmut Holzhey (Berlin: Akademie Verlag, 1996), 45-56.

${ }^{13}$ Isaac Nakhimovsky, "Vattel's Theory of the International Order: Commerce and the Balance of Power in the Law of Nations", History of European Ideas 33, 157-173; Ben Holland, "The Moral Person of the State: Emer de Vattel and the Foundations of International Legal Order", History of European Ideas 37 (2011), 438-445; and Koen Stapelbroek, "Universal Society, Commerce and the Rights of Neutral Trade: Martin Hübner, Emer de Vattel and Ferdinando Galiani”, COLLeGIUM: Studies Across Disciplines in the Humanities and Social Sciences 3 (2008), 63-89.

${ }^{14}$ Vattel, Droit des gens, Preface. 
as civilised entities, governed by accountable statesmen and diplomats who took measured actions. The law of nature indirectly applied also in the realm of the voluntary law of nations and had simultaneously been transformed as well as lifted to the level of the state. Vattel signalled his position in his chosen epigraph for the Droit des gens taken from Cicero: "For to the Supreme God who governs this whole universe nothing is more pleasing than those companies and unions of men that are called cities". ${ }^{15}$ The realm of the political had, as it were, taken over from nature as the frontier of God's creation. The political was not created by God, but it was still based on the same creation with the same moral mission and divine purpose.

Vattel's contemporaries did not fail to pick up his message. As a review of the Droit des gens by the Journal de Commerce in 1759 formulated it: "Mr Vattel considers the principle objects of Good Government, of the Arts, Agriculture and Commerce through the principles of the Law of Nature, on which the good government of these matters that are important both domestically and abroad needs to be based". ${ }^{16}$ In fact, this particular reviewer recognised the Droit des gens as imagining a longterm process of individual state development that shaped the interactions between states in the international realm.

Yet, Vattel has also often been seen as providing a version of (or on the view of others a dissimulating perversion of) the ideas of Christian Wolff, the Prussian moral philosopher who Vattel himself declared to be following to a large extent and whose ideas he said to intended to make available to "a greater number of readers". ${ }^{17}$ Vattel's declared adherence to Wolff's view may be understood as a recognition on the part of Vattel that Wolff's outlook on human sociability best described how the international realm could form a sustainable entity without imposing intervention, arbitration and coercion. However, for Vattel, Wolff's theory of sociability showed, against Wolff's own conclusions, how human nature provided a substantial basis for improvement of the international environment of trade rivalry and war. ${ }^{18}$ While Vattel emphasised the

\footnotetext{
15 “Somnium Scipionis" (“Scipio's Dream”) in Cicero, De republica.

${ }^{16}$ Journal de Commerce (1759), 141-142.

${ }^{17}$ Vattel declared his adherence to Wolff's principles in the Preface.

${ }^{18}$ See Emer de Vattel, Questions de droit naturel et observations sur le Traité du Droit de la nature du M. le Baron de Wolff par M. de Vattel (Bern, 1762).
} 
fundamental flaw in the traditional parallel between individuals living under a civil law and the multitude of states that existed in the world, which, as historians have often stressed, naturally led to a minimal conception of natural sociability, he felt that the divided nature of humankind did not call for a superstate legislative force, or the development of strongly regulative public law. ${ }^{19}$

At the beginning of his career, Vattel published numerous short works on moral subjects. ${ }^{20}$ In these writings, Vattel developed his notion of self-interest. Vattel believed that self-interest could explain sustainable social interaction. Whereas many contemporaries believed that self-interest required a countervailing principle, Vattel argued that nothing gave people as much pleasure as helping each other. ${ }^{21}$ The Christian notion of benevolence did not exist in his system, since self-interest needed no counteraction. People derived higher order pleasures and utility from altruism and simultaneously improved their pleasure and social cohesion. Through pleasurable altruism, people "perfected" themselves and grew into tightly connected groups of persons, or nations.

The key to Vattel's idea of self-interest lay in its developmental aspect. As soon as individual basic needs were satisfied, pleasure became

\footnotetext{
${ }^{19}$ See Richard Tuck, The Rights of War and Peace: Political Thought and the International Order from Grotius to Kant (Oxford: Oxford University Press, 1999); Nakhimovsky, "Vattel's Theory of the International Order". Indeed, the reviewer of the Journal de Commerce too in 1759 criticised Vattel for what he deemed an attempt to politically justify the British abuses of the neutrality of trade.

${ }^{20}$ Emer de Vattel, Le loisir philosophique ou Pièces diverses de philosophique, de morale et d'amusement (Genèva, 1747) and his Poliergie ou mélange de literature et de poësie. Par M. de V.*** (Amsterdam, 1757).

${ }^{21}$ The first five essays of Vattel Le loisir philosophique. The recent English re-edition by Liberty Fund (2008), prepared by Béla Kapossy and Richard Whatmore, entitled The Law of Nations has done a lot to make the Droit des gens available to a wider audience. Next to a republication of the text as it was published in London in 1797, the Liberty Fund edition includes the text of three minor essays written by Vattel in the late 1740s. These provide insight into the context of Vattel's early thinking and form an access point for positioning him as a thinker among his contemporaries. The same editors published a full translation of a collection of Vattel's early moral, literary and political works as an article in History of European Ideas in the same year Emer de Vattel's, "Mélanges de littérature, de morale et de politique (1760)", History of European Ideas 34 (2008), 77-103. A number of chapters in this volume also engage with these essays in order to shed new light on the character of Vattel's work in his actual context.
} 
sociable, since it could only be increased by involving the ideas of others. ${ }^{22}$ Humans had a natural yearning for "perfected" civilised self-interest. "Perfection" implied reflection and created mechanisms that checked the quality of social behaviour. Here, Vattel's views seemed close to the views developed by a number of sophisticated Christian moral philosophers across Europe-like Wolff indeed. ${ }^{23}$ Moreover, in apparent agreement with these philosophers, Vattel recognised that the development of higher order pleasures could lead a society in the wrong direction, where pleasures were at odds with the law of nature and the actual workings of the natural and social world, which made them false pleasures. However, in defining what was required for a society to retain its stability and accordance with the law of nature, Vattel set much greater store by the self-equilibrating mechanisms of human nature than Christian thinkers who called for political guarding of public virtue. In his early writings, Vattel flirted with sceptical tropes and explained through clever sociological observations how games were a socially productive pastime and how people were naturally inclined, as a form of socially stabilising self-deceit, to believe in the afterlife. ${ }^{24}$ According to Vattel, to explain society it was "more natural and more solid" to start from the human urge to strive for happiness, rather than a metaphysical theory of moral obligation. ${ }^{25}$ In contrast, Wolff's moral philosophy started with an idea of moral obligation. Thus, while Vattel followed a different route in identifying the conditions that monitored social outcomes of individual interest-seeking, he still could see and present himself as a follower of Wolff and distance himself from Epicureanism.

\section{Trade, the State and the Balance of Power}

Coming to the political meaning of the Droit des gens, Vattel saw, parallel to the perfection of individuals as hinging on sociable self-interest, the perfection of states as derived from appropriate economic development. The long review of the Droit des gens, published in 1759 in the April and May issues of the Journal de Commerce, noticed that Vattel's natural law

\footnotetext{
${ }^{22}$ Vattel Le loisir philosophique, passim; Vattel, Poliergie passim.

${ }^{23}$ Vattel, Questions de droit naturel.

${ }^{24}$ Vattel Poliergie, notably the essays reflecting on ancient and modern moral philosophy.

${ }^{25}$ Journal de Commerce (1759), 5.
} 
theory matched his economic ideas of "the true principles [... of the most natural order". ${ }^{26}$ Within this order Vattel attached a primary importance to agricultural development, not to trade and luxury, which had since the later seventeenth century taken centre stage in political efforts to spur economic growth. States could rise to greatness, and all states together benefit from each other's greatness within a stable balance of power if agriculture was accepted as the key to economic growth. The Journal de Commerce emphasised the central role of agriculture in Vattel's Droit des gens and identified him as a potentially radical anti-Colbertist. ${ }^{27}$

The theoretical problem put at the outset of the Droit des gens with must be seen in this light. In the opening pages, Vattel criticised the entire history of natural law discourse and professed his allegiance to Wolff, who had insisted that natural law had to be adopted as a moral code for states, as much as for individuals. Vattel argued that the parallel could neither be loose, like Grotius had allowed it to be as a result of which the "common consent of mankind" was the source of a mere "Arbitrary Law of Nations"; nor be too strict and mirror the form of law that regulated the behaviour of citizens in the state, like Wolff had suggested who wanted to see the natural law for states as "the civil law ... of a great republic (civitatis maxime) instituted by nature herself, and of which all nations of the world are members". ${ }^{28}$ For Vattel, there was no necessary contradiction in that there was a real, non-voluntary connection of political decision-making to the law of nature, but that at the same time it could not be denied that states were independent, sovereign and had the kind of rights and liberties that made the international order look like a state of nature. In eighteenth-century Europe, interstate rivalry had become a problem because the politically engendered and mistaken economic "perfection" of societies had led to an imperfect integration of nations in their relations towards each other.

Vattel, then, was highly aware of the necessity for reform, as well the complications standing in the way. It would seem as though Vattel saw states behaving in the international realm the way individuals would who

${ }^{26}$ Journal de Commerce (1759), 141.

${ }^{27}$ Journal de Commerce (1759), 152-155.

${ }^{28}$ For a discussion of these relations Tuck, The Rights of War and Peace, 192 and Journal de Commerce (1759), 137-141. See also Richard Devetak, "Law of Nations as Reason of State: Diplomacy and the Balance of Power in Vattel's Law of Nations", Parergon 28 (2011), 105-128. 
had been oversocialised and made sensitive to pride, dignity and honour, without possessing lower order socialised selfish faculties. The real problem was the existence of an unnatural competition between states that had arisen because national economies had not developed and integrated with each other in the way they should have, as a result of which belligerents used sovereign rights to interfere with other states' trade. The same rights, he argued, were permitted to be deployed to monitor the balance of power through the creation of a well-calibrated system of commercial treaties that shaped patterns of commercial exchange and the internal hierarchy and relative force of Europe's globalised national economies. ${ }^{29}$ Here lay a major challenge to deal with. Mutual aid among individuals as well as states was a basic principle of natural law that Vattel had adopted from Wolff. But it was a matter of general European debate through what economic policies this moral principle could be realised and thereby reform the interstate system. Rather than just stipulate that natural law dictated the integration of national economies insofar as they were complimentary and resulted from the cultivation of available natural resources and to derive whatever principles of free or protected trade from this, by declaring the balance of power the object of the voluntary law of nations Vattel made commerce subservient to the realisation of a political ideal-i.e. the stability of the balance of power. With regard to commercial treaties, states thus remained free to conclude such treaties that in their view stabilised the balance of power and ultimately protected mutual aid among states. ${ }^{30}$

The second part of the review of the work by the Journal de Commerce (of May 1759) from the start was highly critical of Vattel's Droit des gens. It argued that on Vattel's account the freedom to act upon one's needs to protect one's own interest, that Vattel recognised in international law, gave states like England the right to destroy the commerce of neutral states. The reviewer concluded that Vattel, despite his "formal" recognition of the importance of trade for the law of nature and the progress of nations did not come to any legal-political solution

\footnotetext{
${ }^{29}$ Nakhimovsky, "Vattel's Theory of the International Order".

${ }^{30}$ See also the chapters by Alimento and Stapelbroek, as well as Bruno Arcidiacono, "De la balance politique et de ses rapports avec le droit des gens: Vattel, la "guerre pour l'équilibre" et le système européen", Vattel's International Law from a XXIst Century Perspective, 77-100.
} 
that was an improvement upon the actual practice that turned Europe into an arena of economic warfare.

While this judgement of Vattel's Droit des gens by a contemporary is representative for the work's polarised reception ever since its publication, it does not do justice to Vattel's outlook on the resolution of interstate conflict. In fact, Vattel directly engaged with the key political challenges of its time through very narrowly circumscribing war as a situation in which a state rightly pursued its laws by strength ${ }^{31}$ and tried to align this notion of war as a sanctionative juridical instrument with a framework for the reform of European politics. ${ }^{32}$

The cornerstone of Vattel's political thought was the idea of legal autonomy, which connected his notions of individual self-preservation and perfection to the concept of the state. Vattel postulated-as perhaps the first in Europe to do so-the distinction between constituting power as political will and constituted power. ${ }^{33}$ As a consequence, "a nation has an indisputable right to form, maintain, and perfect its constitution", while, as regards legislative powers, "the nation may intrust the exercise of it to the prince, or to an assembly; or to that assembly and the prince jointly". ${ }^{34}$ On this basis, each society of men that had united itself politically was, according to natural law, free and sovereign, irrespective of what degree of power or political and economic autonomy it possessed. Even when placed under the protection of another state, or in a situation of military inequality, a state remained free and sovereign. Vattel famously reasoned that states, as societies of men, stood in the same relation towards one another as regarded their rights and obligations as individuals within any state: just as a dwarf is equal in form to a giant, so a

${ }^{31}$ E.g. Vattel, Droit des gens, book III. See Zurbuchen, "Vattel's Law of Nations and Just War Theory".

${ }^{32}$ Nakhimovsky, "Vattel's Theory of the International Order" and Stapelbroek, "Universal Society, Commerce and the Rights of Neutral Trade".

${ }^{33}$ Vattel, Droit des gens, book I, par. 31, 34. While Vattel has too often been seen as an international lawyer, his underlying constitutional thinking was conceptually innovative and ought to be compared to the language of the constituent that was present in his contemporary Rousseau's writings. See Joel I. Colón-Ríos, "Rousseau, Theorist of Constituent Power", Oxford Journal of Legal Studies 36 (2016), 885-908; and from there Theodore Christov, "Vattel's Rousseau: ius gentium and the Natural Liberty of States", Freedom and the Construction of Europe, ed. Quentin Skinner and Martin van Gelderen (Cambridge: Cambridge University Press, 2013), 167-187.

${ }^{34}$ Vattel, Droit des gens, book I, par. 31. 
small republic cannot be considered less than a sovereign state or a powerful kingdom. ${ }^{35}$

In this way, Vattel forged a shift away from the focus on dynastic, economic and military interests of Europe's dominant territorial monarchies and their struggle for hegemony and placed the well-being of society in the legal foreground. ${ }^{36}$ Ultimately, it was this shift that followed from the basic principles of Vattel's political thought that would turn him into a leading light for politicians of small states who sought to break out the idea that the only hope of survival consisted either in maintaining perfect passive neutrality and political moderation aimed at self-preservation, or seek refuge with a hegemonic state.

Parallel to the idea that the main aim of the Droit des gens was to provide a logic for the rationalisation of interstate conflict, ${ }^{37}$ the work offered an outlook onto interstate trade rivalry. This is how its discussion of commercial neutrality is best understood as being more than an arbitrary compromise between the neutral right to trade and the belligerent right to intercept trade out of necessity. In line with his idea of perfection and regulated luxury, Vattel advocated a law of neutrality that separated trade in higher end-mistakenly presumed to be directly "perfecting"-goods from the more essential and fundamental need-based trade of subsistence goods. ${ }^{38}$ The first kind of trade remained subject to all the rights that states had to regulate foreign trade; the second was to be considered an inviolable realm of natural, politically neutral, exchange between individuals.

Based on the same principles, Vattel also approached the topic of emigration and considered the rights and duties of citizens as well as the state in light of the subsistence needs of people. ${ }^{39}$ Likewise, he built in

${ }^{35}$ On Vattel and "small state theory", Maurizio Bazzoli, Il piccolo Stato nell'età moderna. Studi su un concetto della politica internazionale tra XVI e XVIII secolo (Milan: Jaca Book, 1990), 1151; Small States in International Relations, ed. Christine Ingerbritsen (Reykjavik: University of Iceland Press, 2006); and Domokos Kosary, Les "petits Etats" faceaux changements culturels, politiques et économiques de 1750 à 1914 (Lausanne: HU Jost, 1985).

${ }^{36}$ Vattel, Droit des gens, Preliminaries, par. 18.

${ }^{37}$ Nakhimovsky, "Carl Schmitt's Vattel and the Law of Nations".

${ }^{38}$ Nakhimovsky, "Vattel's Theory of the International Order".

${ }^{39}$ See the chapter by Carrera. In addition see Vincent Chetail, "Sovereignty and Migration in the Doctrine of the Law of Nations: An Intellectual History of Hospitality from Vitoria to Vattel”, European Journal of International Law 27 (2016), 901-922. 
the option that a group of citizens, formed a nation and could break away from the fatherland. The Dutch Revolt and, ultimately, ensuing independence of the United Provinces in this regard was justified by Vattel.

At the same time, not in the realm of self-determination and subsistence, Vattel discussed the legal restrictions that ought to exist with regard to (private) investment in foreign state debts by citizens of neutral states, which emphasised the idea that such investments should not in any way be politically interested (even if such investments led to spending on warfare), i.e. interest payments had to be in accordance with market conditions. ${ }^{40}$ In the process of dealing with political vis-à-vis commercial relations between citizens of different states and by opening up questions about obligations and rights emanating from treaty arrangements, Vattel discussed political neutrality and trade in relation to each other more than any writer had done before, in order to respond to the problem of neutral trade in the War of the Austrian Succession.

These issues of war and trade were discussed when Vattel's Droit des gens first appeared in the midst of the Seven Years' War. Vattel's work, however, responded to a longer succession of military conflicts and their resolution that took place through crafting a balance of power. Vattel discussed many examples of cases that belonged to the context of the War of the Austrian Succession, the first major European conflict following the attempt at the Peace of Utrecht in 1713 to fix an enduring peace that included a set of commercial treaties that configured the exchange and power relations between European states.

In the light of previous earlier eighteenth-century settlements and their use of peace and commercial treaties, the Droit des gens appears an attempt to further contribute to the legal and political apparatus in support of these settlements. It has often been noted that in practical terms, Vattel hailed the British take on international trade and relations with smaller states (where respect for legal autonomy and military protection were combined) as a model for Europe as a whole, much like Genevan political writers who likewise admired the British constitution and deemed it a crucial guarantor for European liberty would echo Vattel's praise several decades later. ${ }^{41}$

\footnotetext{
${ }^{40}$ Vattel, Droit des Gens, book III, par. 110.

${ }^{41}$ Richard Whatmore, Against War and Empire: Geneva, Britain and France in the Eighteenth Century (New Haven: Yale University Press, 2012), 103-118, 257-260.
} 


\section{Vattel's Concepts, Small States and the Reception OF THE DROIT DES GENS}

The big question of the seventeenth and eighteenth century was whether sociability could be a basis for politics. Natural lawyers from Grotius and Hobbes onwards had tended to minimise the scope for arguing that it could. ${ }^{42}$ By the Seven Years' War, this question had become highly politicised and become part of the belligerent conflicts of the time. Vattel was adamant that his Droit des gens did not represent a position for either a French, British or whatever vision of the principles of international politics. The Droit des gens was not to be understood or used as a pamphlet-even though it was and would also be hijacked and published twice for political purposes immediately upon its original appearance. ${ }^{43}$

While Vattel's answer was a qualified confirmation that indeed sociability could be a basis for politics, he was criticised from the moment the Droit des gens appeared until deep into the twentieth century, on the one hand for creating an inlet for legitimating warfare in the name of justice and on the other for his supposed reliance on positivist structures to curb belligerent conflict.

In putting forward his Droit des gens as a framework for European politics, Vattel used his conceptual lexicon to distinguish between different types of law in order to carve out an appropriate space for the law of nations and the appropriate discretionary force field within which political decision-making existed. ${ }^{44}$ Within this legal system, there was still the possibility that sovereign actions, including by European monarchs, would be punishable under the law of nature, though this would be exceptional. In fact, among the relatively few occasions that Vattel's political shone through in the Droit des gens were his rejections of Frederick II as an "enemy of humankind",

\footnotetext{
${ }^{42}$ Tuck, The Rights of War and Peace.

${ }^{43}$ See the chapters by Alimento and Stapelbroek. We refer to the Luzac edition and the parts published in the Memoires French foreign-ministry campaign series that was a spin-off from the Observateur Hollandois.

${ }^{44}$ See the chapter by Malt.
} 
which were shared among other writers on the law of nations across Europe. ${ }^{45}$

During the late eighteenth and early nineteenth century, Vattel's constitutional and political vision of Europe moved more to the mainstream and might be recognised in other writers' views, such as those of Joseph-Mathias Gérard de Rayneval and a number of British writers. Yet, in the time around this period, from the Seven Years' War to Cornelis van Vollenhoven's infamous allegation of having given a positivist "Judas kiss" to Grotian international law, Vattel's legal-political legacy can to some extent be reconstructed as an oscillation between both the critiques of too easily prohibiting and too easily condoning just war, and some recent contributions to intellectual history have indeed done so. ${ }^{46}$

Nonetheless, in parallel to Vattel's capacity for serving as a lightning rod attracting critiques from opposite ends of the juridical spectrum, it was the manner in which he had developed his notion of the law of nations and connected it to a conceptual vocabulary that had given the Droit des gens a different kind of legacy. Here, the key themes were not war and foreign intervention, but constitutional integrity, the idea of the nation and the autonomy of small states. It was this reception history and legacy of Vattel that can be traced through Europe's small states and republics, especially the old Italian ones that were reduced to mere auxiliary states of Europe's powerful dynasties and commercial powerhouses in the eighteenth century. In these contexts, Vattel's legal-political system, emphasising the values of sovereignty and legal equality among states offered a valuable guideline and support for Italian states in navigating the international realm. If Frederick II in his Anti-Machiavel, like many writers such as Hume, recognised the advantages of civil liberty under monarchical government and saw a future of commercial modern

\footnotetext{
${ }^{45}$ See the chapters by Szymanski, Clerici and Ieva. See Walter Rech, Enemies of Mankind: Vattel's Theory of Collective Security (Leiden: Martinus Nijhoff, 2013); Isaac Nakhimovsky, "The Enlightened Prince and the Future of Europe: Voltaire and Frederick the Great's Anti-Machiavel of 1740", ed. Béla Kapossy, Isaac Nakhimovsky and Richard Whatmore (Cambridge: Cambridge University Press, 2017), 44-77.

${ }^{46}$ Cornelis van Vollenhoven, De drie treden van het volkenrecht. On Schmitt and Koselleck and recent interpretative "oscillations", see Nakhimovsky, "Carl Schmitt's Vattel and the Law of Nations"; Béla Kapossy, "Rival Histories of Emer de Vattel's Law of Nations", Grotiana 31 (2010), 5-21. On the practical diplomatic usage of Vattel in justifying and rejecting war, see Jennifer Pitts, "International Relations and the Critical History of International Law", International Relations 31 (2017), 282-298.
} 
monarchies squeezing functionally extinct small states and republics out of the political landscape, Vattel's vision of a pacified European society offered a more hopeful prospect. ${ }^{47}$ One that helped smaller states and republics shape their constitutional identity and deal with the international legal challenges (in staying neutral in war and in maintaining commercial relations) that occurred in the turbulent contexts of the mid- and later eighteenth century. It is for this reason that a number of chapters in the volume are dedicated to Vattel's legacy in eighteenth-century Italian contexts.

But the language of independence, the constituent nation of the state and legitimate sovereignty did not just show in the older fragmented parts of Southern Europe and the Mediterranean, including also the Swiss states. A paradigmatic case where Vattel's conceptual lexicon was invoked was of course the American one where from the Declaration of Independence to the Constitution, Vattelian concepts fulfilled an important function. ${ }^{48}$

Apart from the specific American case, it can be observed that following the Napoleonic Wars, the time of the Congress of Vienna saw a new form of application of Vattel's theoretical structure for understanding states as dependent upon the nation, but themselves as the key elements and subjects in the international system. The treaties that were concluded around the Congress of Vienna on the one hand maintained sovereign states and rulers as the signatories of the documents that were sanctioned by the great powers dictating the terms of the international order through the Quadruple and Quintuple Alliance. On the other

${ }^{47}$ Richard Whatmore, "Vattel, Britain and Peace in Europe", Grotiana 31 (2010), 85-107. In the Dutch Republic, the vision of Frederick II and shared by Johan Heinrich Gottlob von Justi was taken up as a wake-up call that the Republic need to be reformed, see Koen Stapelbroek, "The International Politics of Cameralism: The Balance of Power and Dutch Translations of Justi", Cameralism Across the World of Enlightenment: Nature, Happiness and Governance, ed. Ere Nokkala, Nicholas B. Miller and Dominik Hünniger (London: Routledge, forthcoming).

${ }^{48}$ See William Ossipow and Dominik Gerber, “The Reception of Vattel's Law of Nations in the American Colonies: From James Otis and John Adams to the Declaration of Independence", American Journal of Legal History 57 (2017), 521-555; Vincent Chetail, "Vattel and the American Dream: An Inquiry into the Reception of the Law of Nations in the United States", The Roots of International Law/Les fondements du droit international, ed. Vincent Chetail and Pierre-Marie Dupuy (Leiden: Martinus Nijhoff, 2013), 251-300. Against mythical "originalism", Brian Richardson, "The Use of Vattel in the American Law of Nations", American Journal of International Law 106(3) (2012), 547-571. 
hand, the underlying motivations for the creation and recognition of new states and constitutions as part of the treaty process fit neatly with the more prominent role that the idea of the nation started to play at the time, very much in line with how Vattel conceived of the nation as the conceptual hinging point between the law of nature and the positive aspects of the voluntary law of nations. Vattel's Droit des gens was a logical reference point in the early nineteenth century when justifying the post-Vienna international order. Unsurprisingly, Vattel's legacy in the nineteenth century cannot be seen independently from the formation of the nineteenth-century state system and its development. If, in the early twentieth century, the treaty system was considered a product of Vattelian international law, the restrictions on sovereignty and state power that Vattel had introduced as integral parts of the structure of his law of nations tended to be overlooked. In this sense, the years preceding World War I, with the third The Hague Peace Conference, Van Vollenhoven's call for an international police force and the lead up to the League of Nations presented a relapse into a pre-Vienna, and in fact pre-Utrecht, predicament as the meltdown of a presumed Vattelian system of international law. ${ }^{49}$

The contributions to this volume highlight the various ways in which Vattel's conceptual innovations have been understood, used, diffused and put into practice over a period of time stretching from the publication of the Droit des gens to the nineteenth century.

The first part of the volume, consists of six chapters that focus on Vattel's ideas and his context. In the first chapter of Part I of the volume, Radoslaw Szymanski zooms in on aspects of the career of Vattel as a diplomat and the networks between the economic society of Berne, Saxony and Poland. Vattel was exposed to and participated in various of these reform movements. The active role played by Vattel in establishing connections between different reform circles, notably between the economic reform groups in Bern and the reform parties in Poland and Saxony generates a better understanding of the kind of economic and

\footnotetext{
${ }^{49}$ For an explanation of the Peace of Utrecht (1713) as constitutive of an international (commercial and political) order, see Koen Stapelbroek and Antonella Alimento, "Trade and Treaties: Balancing the Interstate System", The Politics of Commercial Treaties in the Eighteenth Century: Balance of Power, Balance of Trade, ed. Antonella Alimento and Koen Stapelbroek (Basingstoke: Palgrave Macmillan, 2017), 1-75.
} 
political reforms Vattel considered necessary for a stable European state system to come into effect.

The chapter by Frédéric Ieva uses personal correspondence by Vattel with figures, notably Samuel Formey, in his diplomatic and literary network to shed new light on the genesis of the Droit des gens and further shows how biographical descriptions that appeared in the second half of the eighteenth and early nineteenth century echoed the doctrinal divisions between positive and negative assessments and contained numerous errors about basic facts of Vattel's life.

Alberto Carrera, in his contribution, highlights the concept of exile in the Droit des gens and shows how his combined perspective of natural law and the law of nations generated Vattel's outlook on an individual's right to leave the country and the right to live somewhere to provide one's own subsistence. By considering what political rights, and vice versa what duties, citizens had to leave their country and what natural rights individuals had, Vattel intervened in the international political, military and social debates of the period of the Seven Years' War and provided answers to questions that were raised by conflict, territorial occupations and population displacement.

The chapter by Koen Stapelbroek reconstructs Vattel's attitude towards Britain in the Seven Years' War in order to explain why book II and III of the Droit des gens might be republished, in 1759, in the French foreign-ministry campaign publication that sprang from the Observateur Hollandois. It emerges that Vattel, indeed, was an admirer of the British constitution, but also a critic of the British "mercantile system" and its cynical foreign politics that helped trigger the Seven Years' War. When the first edition of Vattel's Droit des gens was immediately republished in a French propaganda publication, this made perfect sense in view of the French foreign policy contexts of the time. Moreover, Vattel's attitude towards Britain was not a strange combination of contrasting positions, but followed from his fundamental political thought. In fact, Vattel's general position on luxury, moral philosophy and commercial sociability resembled that of other contemporaries who were equally concerned with the legacy of the Peace of Utrecht and the challenge to turn the balance of power into a durable system of peace and international trade.

Concluding Part I of the volume, Antonella Alimento's contribution dovetails neatly with the observation that Vattel, the presumed anglophile, was also critical of Britain. In her chapter, she analyses 
the reception of the Droit des gens in France by examining the correspondence of 1757 and 1758 between Vattel and the director of the Librairie, Chrétien-Guillaume Lamoignon de Malesherbes, as well as a contextual analysis of references to the work in French diplomatic papers written at the time of the Seven Years' War, attest to the fact that Le Droit des gens enjoyed the approval of the leading minister of the time, Étienne-François de Choiseul, and was also well received by the group of administrators and intellectual-diplomats-including Malesherbes himself - who gathered around Vincent de Gournay and gave rise to the "new science of commerce". These men had in fact developed a geopolitical strategy that overlapped with the vision of economic development and interstate relations set out by Vattel in his treatise.

The second part of the volume consists of six more chapters that chart the reception of the Droit des gens in the old Italian states, small states around the northern Mediterranean, in Norway around 1814 and more generally in the nineteenth century. While Part I reinterpreted some of Vattel's positions and concepts within their original context, Part II is specifically aimed at understanding, not so much how Vattel's thinking about war and peace was considered in later times, but how Vattel's conceptual lexicon was adopted and given new functions beyond the political, legal and economic contexts in which they were formulated.

In the first chapter of Part II, Antonio Trampus analyses important aspects of the reception of Vattel's Droit des gens in Corsica, Switzerland and the German states-especially through a manuscript at the public library of Berne-from the second half of the eighteenth century to the period of the post-Napoleonic Restoration of 1814-1830. It is demonstrated that Vattel's outlook onto the idea of good government was profoundly related to the idea of the sovereignty of small states and had a great appeal not only in theory but also as a guide to domestic constitutional, social and economic reform. Likewise, the Göttingen manuscript provides a perspective on how the impartial political and legal theory of Vattel (which was deliberately sober in giving examples) was understood to chime with the reality of international politics from the Seven Years' War to the early nineteenth century.

The chapter by Danilo Pedemonte reconstructs the reception of Vattel's Droit des gens in the Republic of Genoa, considering its diffusion from an unusual perspective. This chapter deals with the traces that the Droit des gens left in the everyday operations of Genoese magistrates and 
focuses especially on the neutrality proclamation of 1779 and the accompanying law that represented the first Genoese attempt that helped to transform customary neutrality into an internationally accepted written norm. This law was inspired by one of the hallmarks of Vattel's thinking, the identification of the legitimacy of small states to claim the exercise of sovereign autonomy on the international scene. The analysis of the Genoese case is compared with the Tuscan declaration of neutrality of the same year, where the usage of the Droit des gens was altogether more direct, full and self-conscious.

The contribution by Alberto Clerici shifts the perspective to the Papal State between 1756 and 1766. Its main argument is that the very first diffusion of Vattel in those territories was directly linked to the geopolitical dynamics resulting from the Seven Years' War, with particular reference to the clash, both military and ideological, between Frederick II of Prussia and Maria Theresa of Austria. The chapter focuses especially on the figure of the Celestine monk Appiano Buonafede (1716-1793), whose The Most Famous Conquests Examined with the Natural Law of Nations (1763) was among the first and most interesting attempts to re-elaborate the modern theory of ius naturae et gentium in Italy, as well as one of the first testimonies of the influence of Vattel in the Papal States. This critique of Prussian propaganda took into account three specific issues: pre-emptive strikes as just causes for war, the rights of victory over the enemy in a just war and, finally, the pursuit of glory in the imitation of the Ancients.

Gert-Fredrik Malt, in his chapter, discusses Vattel's system of concepts for subjects in international law, especially the concepts sovereign, people, state, nation and power. Malt emphasises Vattel's innovative development of the comprehensive system of concepts, especially that of the nation, and stresses their usage in the construction of a pluridimensional theory of subjects in international law, with both descriptive and normative elements. Vattel's system fairly neatly corresponded to the manner in which the concept nation became a recognised hinging point in the discussions about international politics that crystallised in the later eighteenth century and following the Napoleonic Wars around the time of the Congress of Vienna. In fact, the manner in which accepted notions of the Norwegian nation found their way in the field of international diplomacy after the Treaty of Kiel of 1814 suggests that Vattel's conceptual system had a real impact on the recognition of the Norwegian constitution within the nineteenth-century state system. 
Finally, Elisabetta Fiocchi Malaspina analyses the circulation of Vattel's Droit des gens in the nineteenth century, the period in which it enjoyed its greatest success. The numerous editions and early translations produced throughout the eighteenth century enabled the broad dissemination of Vattel's Droit des gens. Yet, the Droit des gens had an extremely diverse impact, owing to its varied reception in different political situations, historical and legal contexts, and attempts at practical and theoretical implementation. The chapter first reconstructs the historical development of nineteenth-century international law, with particular regard to the universalisation of (European) international law, and, second, discusses the translations of the Droit des gens and its spread in Latin America.

Although in recent times, the international historiography has recognised the problems that are inherent to the multifarious Vattel reception, the disciplinary fragmentation among historical, legal and international orientations towards the Droit des gens has had ramifications for the current understanding of Vattel's legacy. The contributions to this volume aspire to provide a further step not only in reconciling the various disciplinary approaches to Vattel's Droit des gens in a more comprehensive scholarly understanding, but also to offer a methodological reference point for further studies of this kind.

While it is our hope that scholars engaging with national contexts in which Vattel's work had an influence will find the transnational approach of this volume useful, and we likewise hope to offer insights on Vattel's Droit des gens that will be picked up by scholars in a wide range of disciplines, the ultimate ambition of this book is of a different kind. The aim of the book to offer a new paradigm for thinking about the reception of ideas and the creation of intellectual legacies through the subject of Vattel's Droit des gens transcends the interest of the case study itself. The volume may be read or used as an anthology, but its true character is to connect the spheres of practice (reception, appropriation and usages) and theory (ideas and texts). Vattel's legacy, as the book as a whole brings out in an entirely new way, cannot be understood in the function of the present or an isolated past, but has to be charted along its various discursive, lexical, legal, political and diplomatic contexts of reception. In the final instance, it was the capacity of the book to be received, not its "own" purpose, that made for the multifarious nature of the book's legacy and determined its role in the development of modern politics, law and diplomacy. 


\section{A Note on the Text and Editions}

Given the nature of this volume, which engages with the reception, diffusion and translation of ideas through different editions in different languages, certain choices had to be made regarding the citation of Vattel's Droit des gens and the presentation of the editions of the work. Throughout the book, references will take the same standardised form including the book, chapter, and paragraph of the Droit des gens, so as to help readers using different standard editions of the text (in different languages) to engage with the contributions to this volume.

Most contributors quote from the recent, widely available, English language edition of 2008, which maintained the text and English title The Law of Nations: Or, Principles of the Law of Nature Applied to the Conduct and Affairs of Nations and Sovereigns of the London 1797 standard edition. References to this English language edition, however, still take the same form as above, citing Vattel, Droit des gens, book, chapter, paragraph.

In cases where differences in language, concepts or contexts are relevant and are part of the argument of the chapter, references are to and quotations are from further specified editions or unpublished translation manuscripts. 